\title{
MENGOPTIMALKAN HASIL BELAJAR MELALUI PEMBELAJARAN REMEDIAL
}

\author{
Nasruddin Hasibuan \\ IAIN Padang Sidempuan, Sumatera Barat, Indonesia \\ nasruddinhasibuan@yahoo.co.i ${ }_{\mathrm{d}}$
}

\begin{abstract}
Abstrak
Istilah remedial di lembaga pendidikan formal adalah kegiatan yang terprogram. Kegiatan ini dilaksanakan oleh guru mata pelajaran dan tetap dalam pengamatan kepala sekolah. Hadiah remidi ini sebagai tanggung jawab untuk belajar melaksanakan tugas studi. Remidi di lembaga pendidikan formal, sekolah Islam dan juga sekolah umum adalah masalah yang sangat penting, karena remidi yang baik akan dapat mengantarkan siswa ke dalam proses pembelajaran yang efektif dan efisien. Penelitian studi kepustakaan ini meneliti tentang cara mengoptimalkan hasil belajar dengan menggunakan remidial. Kesempatan remidi ditentukan oleh proses presentasi pelajaran sesuai dengan kurikulum yang digunakan. Banyak sekolah yang kurang memperhatikan kesempatan remidi dapat membahayakan siswa dalam pencapaian skor belajar. Remidi dalam perjalanan pembelajaran dijalankan sesuai dengan tingkat pencapaian hasil belajar siswa. Adapun prinsip remedial adalah adaptif, interaktif, intensif, fleksibel, adanya umpan balik, kesinambungan dan ketersediaan
\end{abstract}

Kata kunci: pembelajaran, remedial, hasil belajar.

\begin{abstract}
OPTIMIZING LEARNING OUTCOMES THROUGH REMIDIAL LEARNING. The Remedial term in formal education institute is a programmed activity. This activity is executed by subject
\end{abstract}


teacher and stays in the headmaster observation. Remedial gift is as responsibility for learning to its duty in executing the study duty. Remedial gift in formal education institute, goodness of Islamic school and also public school are very crucial matter, because the good remedial gift will be able to squire the students into efficient and effective learning process. This library research examined about the way how to improve students' learning result. The remedial gift is determined by the process of lesson presentation according to curriculum that is used. A lot of schools which are less paying attention to the gift remedial can harm the student in the learning scoring achievement. Remedial gift in the course of learning is executed by pursuant to the level achievement of result of students' learning. The principles are adaptive, interactive, intensive, flexible, feedback, continuity and availability.

Keywords: remedial learning, students' learning achievement

\section{A. Pendahuluan}

Belajar sebagai bagian dari kebutuhan hidup manusia untuk berusaha mengembangkan aspek kemampuan psikis, seperti kemampuan berpikir, kemampuan mengingat, kemampuan menelaah dan kemampuan lainnya. Untuk pendidikan formal anak akan berhadapan dengan berbagai sistem pembelajaran yang dibimbing oleh guru. Termasuk dengan sistem menghafal pelajaran yang disampaikan guru. Walaupun sistem pembelajaran seperti ini terkesan konvensional atau metode tradisional yang sudah dijumpai dari sejak dulu, hasil penelitian dan pendapat para ahli sekarang ini lebih menyempurnakan konsep tradisional di atas masih tepat untuk diterapkan.

Kegiatan belajar di sekolah dibimbing para guru sesuai dengan bidang atau mata pelajaran. Sehingga para guru berusaha semaksimal mungkin dala mengajar agar para peserta didik dapat mengikuti pelajaran dengan baik. Menurut Kamus Bahasa Indonesia (2008: 24), mengajar adalah memberikan serta menjelaskan kepada orang tentang suatu ilmu; memberi pelajaran atau dalam kata lain adalah melatih. Lebih lengkapnya lagi, mengajar adalah penciptaan sistem lingkungan yang memungkinkan terjadinya proses belajar. Mengajar menurut pengertian mutakhir merupakan suatu perbuatan yang kompleks.

Kaitannya dengan mengajar, sistem lingkungan yang ada di sekolah terdiri dari komponen-komponen yang saling mempengaruhi, 
yakni tujuan instruksional yang ingin dicapai, materi yang diajarkan, guru dan siswa yang memainkan peranan serta ada dalam hubungan sosial tertentu, jenis kegiatan yang dilakukan, serta sarana dan prasarana belajar mengajar yang tersedia. Kedudukan guru dalam pengertian ini sudah tidak dapat lagi dipandang sebagai penguasa tunggal dalam kelas atau sekolah, tetapi dianggap sebagai fasilitator dan mediator yang harus memberikan fasilitas atau kemudahan dalam proses belajar mengajar dan sebagai penengah dalam kegiatan belajar siswa (Sardiman, 2011: 146). Namun, saat ini masih sering kita temukan kegagalan siswa atau mahasiswa dalam proses kegiatan belajar mengajar.

Berpijak dari permasalahan di atas, manakala ada kesulitan atau kegagalan yang dialami oleh siswa atau mahasiswa, guru atau dosen harus senantiasa membantu dan memfasilitasi mereka agar benar-benar mencapai kompetensi yang diharapkan. Berdasarkan teori dan permasalahan yang tersebut, penulis ingin mengetahui peranan remedial dalam mengoptimalkan hasil belajar. Dengan menganalisis beberapa referensi atau melakukan studi kepustakaan, penulis berharap akan memperoleh jawaban terbaik kaitannya dengan peranan remedial dalam mengoptimalkan hasil belajar. Adapun studi kepustakaan sendiri menurut Nazir (2003: 112) studi kepustakaan merupakan langkah yang penting dimana setelah seorang peneliti menetapkan topik penelitian, langkah selanjutnya adalah melakukan kajian yang berkaitan dengan teori yang berkaitan dengan topik penelitian.

\section{B. Pembahasan}

\section{Pengertian Remedial dalam Kegiatan Pembelajaran}

Banyak guru beranggapan bahwa remedial sebagai program baru yang diterapkan di sekolah, sehingga mereka merasa terbebani dan semakin berat dalam melaksanakan tugas. Remedial selama ini masih banyak dilaksanakan di tingkat perguruan tinggi, seperti remedial bahasa. Padahal remedial secara hakikat sudah selalu dilaksanakan guru di sekolah, hanya saja tidak terprogram sebagaimana yang diharapkan dalam sistem pendidikan sekarang. Tahapan-tahapan pembelajaran adalah sebagai langkah yang meliputi persiapan awal sampai kepada pelaksanaan diatur secara sistematis. 
Setiap guru harus mengawali kegiatannya dari menyusun rencana pembelajaran. Rencana pembelajaran atau yang lazim dikenal dengan SAP adalah kumpulan dari beberapa kegiatan yang harus dilakukan guru dalam melaksanakan tugas pembelajaran. Menurut Majid (2011: 16), Memang tidak ada format baku dalam penyusunan persiapan mengajar. Dengan demikian guru diharapkan dapat mengembangkan format-format baru. Tidak perlu ada keseragaman format, karena pada hakikatnya silabus dan rencana pengajaran adalah program guru mengajar.

Dalam hal ini, penulis menyajikan beberapa model persiapan mengajar sebagai bahan pembanding dan stimulus untuk lahirnya model-model baru. Salah satunya yaitu R.O.P.E.S. (Review, Overview, Presentation, Exercise, and Summarize), konsep dari Hunts. Menurut Hunts dalam Rice (2013: 3), ROPES is available to assist educators in organizing course content to enhance learning outcomes (ROPES ada dengan tujuan membantu para pendidik dalam mengorganisasikan isi kelas agar dapat meningkatkan kualitas siswa). Lebih jelasnya sebagai berikut.

1) Review, kegiatan ini dilakukan dalam waktu 1 sampai 5 menit, yakni mencoba mengukur kesiapan siswa untuk mempelajari bahan ajar dengan melihat pengalaman sebelumnya yang sudah dimiliki oleh siswa dan diperlukan sebagai prerequisite (pretest) untuk memahami bahan yang disampaikan hari itu.

Hal ini diperlukan dengan didasarkan atas:

a) Guru bisa memulai palajaran, jika perhatian dan motivasi siswa untuk mempelajari bahan baru sudah mulai tumbuh.

b) Guru hendak memulai pelajaran, jika interaksi antara guru dengan siswa sudah mulai terbentuk

c) Guru dapat memulai pembelajaran jika siswa sudah memahami hubungan bahan ajar sebelumnya dengan bahan ajar baru yang dipelajari hari itu.

Guru harus yakin dan tahu betul jika siswa sudah siap menerima pelajaran baru. Jika siswa belum menguasai pelajaran sebelumnya, maka guru harus dengan bijak memberi kesempatan kepada siswa untuk memahaminya terlebih dahulu atau mencerahkan melalui pemberian 
tugas, penjelasan, bimbingan dan baru bergerak pada materi selanjutnya.

Apabilaterjadiakumulasibahanajaryangtertunda,maka harus dicarikan waktu tambahan, karena lebih baik menunda bahan ajar baru daripada menumpuk ketidakpahaman siswa pembelajaran. Hal ini dimaksudkan untuk memberikan kesempatan kepada siswa untuk menyampaikan apa yang mereka ketahui atas langkah-langkah pembelajaran yang hendak ditempuh oleh guru sehingga berlangsungnya proses pembelajaran, bukan hanya milik guru semata, akan tetapi siswa pun ikut merasa senang dan merasa dihargai keberadaannya.

2) Presentation, tahap ini merupakan inti dari proses kegiatar belajar mengajar, karena di sini guru sudah tidak lagi memberikan penjelasan-penjelasan singkat, akan tetapi sudah masuk pada proses telling, showing, dan doing. Proses tersebut sangat diperlukan untuk meningkatkan daya serap dan daya ingat siswa tentang pelajaran yang mereka dapatkan. Semakin bervariasi strategi pembelajaran yang digunakan, semakin baik proses dan hasil yang dicapai, karena tidak menjadikan siswa jenuh, melainkan mengantarkan mereka menikmati proses pembelajaran dengan suasana asyik dan menyenangkan.

3) Exercise, yakni suatu proses untuk memberikan kesempatai kepada siswa mempraktikkan apa yang telah mereka pahami. Hal ini dimaksudkan untuk memberikan pengalaman langsung kepada siswa sehingga hasil yang dicapai lebi bermakna. Oleh karena itu guru harus mempersiapkan rencana pembelajaran tersebut dengan baik melalui skenario yang sistematis. Misalnya untuk sains bisa dilakuka praktik di laboratorium, untuk bahasa, membaca Alquran mengkafani mayat bisa dilakukan di kelas, jika tidak, sulit bagi guru untuk memberikan pengalaman-pengalama manipulatif melalui berbagai praktikum di sekolah. Disamping itu pula guru harus mempersiapkan perencanaa pengajaran bukan hanya bahan ajar saja, tetapi pengalaman belajar siswa yang harus diberikan lewat peragaan-peragaan, bermain peran dan sejenisnya yang harus ditata berdasarkan alokasi waktu antara penjelasan, 
asignment (tugas-tugas), peragaan dan lain sebagainya.

4) Summary, dimaksudkan untuk memperkuat apa yang telah mereka pahami dalam proses pembelajaran. Hal ini sering tertinggal oleh guru karena mereka disibukkan dengan presentase, dan bahkan mungkin guru tidak pernah mebuat summary (simpulan) dari apa yang telah mereka ajarkan.

Hal yang ganjil dari rencana prosedur pembelajaran yang dikemukakan oleh Hunts adalah tidak mencantumkannya aspek penilaian, padahal hasil penilaian selain mengukur tingkat pencapaian kompetensi siswa, juga dapat dijadikan input untuk melakukan perbaikan pada proses pembelajaran berikutnya. Jika guru tidak mempunyai data dan informasi yang cukup tentang perkembangan siswanya, maka terjadilah penumpukan akumulasi ketidakpahaman siswa yang pada akhirnya menjadi bumerang bagi sekolah itu sendiri, sehingga muncul anggapan sekolah meluluskan siswa dengan potensi di bawah standar minimal penguasaan kompetensi.

\section{Mengefektifkan Kegiatan Pembelajaran Remedial}

Sebelum membahas lebih detil, perlu diketahui bahwa ada tujuh perbedaan anatara pembelajaran biasa dan remidial. Menurut Sutikno (2009: 167) tujuh perbedaan tersebut yaitu:

a. Kegiatan pembelajaran biasa sebagai program pembelajaran dikelas dan semua siswa berpartisipasi, sedangkan pembelajaran remedial dilakukan setelah diketahui adanya kesulitan belajar

b. Tujuan pembelejaran biasa adalah dalam untuk mencapai tujuan pembelajaran yang ditetapkan sesuai dengan kurikulum yang berlaku dan sama untuk semua siswa, sedangkan pembelajaran perbaikan tujuannya disesuaikan dengan kesulitan belajar siswa walaupun tujuan akhirnya sama.

c. Metode yang digunakan dalam pembelajaran biasa itu sama untuk semua siswa, sedangkan metode dalam pembelajaran perbaikan disesuaikan dengan laatar belakang kesulitan.

d. Pembelajaran biasa dilakukan oleh guru, sedangkan pembelajaran pebaikan oleh tim (kerjasama).

e. Alat pembelajran remedial lebih bervariasi 
f. Pembelajran perbaikan lebih diferensial dengan pendekatan individu

g. Evaluasi pembelajaran remidial disesuaikan dengan kesulitan belajar siswa.

Dasar pertimbangan pemberian remedial antara lain ialah untuk mengefektifikan proses pembelajaran. Dasar lain ialah untuk mendalami tingkat kemampuan belajar siswa. Tidak dapat dipastikan apakah siswa telah menguasai dengan pelajaran yang telah disampaikan, karena hal tersebut sangat bersifat objektif, kecuali dilakukan dengan memberikan pretes. Dengan pretes inilah guru akan dapat mengidentifikasi apakah siswa masih mengingat atau sudah mantap dengan pelajaran yang lalu atau belum.

Pelaksanaan remedial selain memberikan tambahan kegiatan pembelajaran, juga sebagai upaya untuk memperdalam materi yang disajikan. Untuk melengkapi penjelasan dan analisa tersebut, kiranya guru dapat memasukan unsur penilaian, karena melalui penilaianlah guru memperoleh gambaran tingkat penguasaan siswa terhadap materi yang disampaikan sehingga dapat mengembangkan materi yang akan disajikan pada pertemuan berikutnya. Remedial sebagai salah satu upaya untuk menciptakan efektivitas mengajar, sebab apabila siswa telah dapat mengikuti semua materi yang disampaikan guru, maka akan tercipta kelancaran proses pembelajaran. Berdasarkan hasil penilaianlah guru dapat mengetahui tingkat efektivitas strategi pembelajaran yuang digunakan. Untuk lebih jelasnya dalam mengefektifkan kegiatan pembelajaran tidak terlepas dari penyusunan perencanaan pembelajaran. Pembelajaran atau proses belajar mengajar adalah proses yang diatur dengan langkah-langkah tertentu, agar pelaksanaannya mencapai hasil yang diharapkan.

Langah-langkah tersebut biasanya dituangkan dalam bentuk perencanaan mengajar. Proses penyusunan perencanaan pengajaran memerlukan pemikiran-pemikiran sistematis untuk memproyeksikan/memperkirakan mengenai apa yang akan dilakukan dalam waktu melaksanakan pengajaran. Remedial harus dipersiapkan secara baik, yaitu diawali dari pengukuran secara objektif tentang kemampuan Siswa dalam menguasai indikator kompetensi dan kompetensi dasar. Remedial harus mempunyai rencana mengajar atau 
persiapan mengajar atau lebih dikenal dengan satuan pelajaran adalah program kegiatan belajar mengajar dalam satuan terkecil, bahwa guru mengembangkan perencanaan dalam bidangnya untuk jangka waktu satu tahun atau satu semester, satu minggu, atau beberapa jam saja.

Untuk satu tahun dan semester disebut sebagai program unit, sedangkan untuk beberapa jam pelajaran disebut program satuan pelajaran, yang dalam implementasi kurikulum 2004 memiliki komponen kompetensi dasar, materi standar, prosedur pembelajaran/ pengalaman belajar, metode dan evaluasi berbasis kelas, serta bahan/ alat yang dugunakan. Secara sistematis rencana pembelajaran dalam bentuk satuan pelajaran adalah sebagai berikut: identitas mata pelajaran (nama pelajaran, kelas, semester, dan waktu atau banyaknya jam pertemuan yang dialokasikan).

Dalam hal menyusun program pembelajaran perbaikan (remedial teaching), Muhibbin Syah (2010: 174) mengatakan bahwa sebelumnya guru perlu menetapkan hal-hal sebagai berikut:
a. Tujuan pengajaran remedial
b. Materi pengajaran remedial
c. Metode pengajaran remedial
d. Alokasi waktu pengajaran remedial
e. Evaluasi kemajuan siswa setelah mengikuti program pengajaran remedial

Kompetensi dasar dan indikator yang hendak dicapai atau dijadikan tujuan dapat dikutip/diambil dari kurikulum dan hasil belajar yang telah ditetapkan oleh pemerintah. Materi pokok (beserta uraiannya yang perlu dipelajari siswa dalam rangka mencapai kompetensi dasar). Media (yang digunakan untuk kegiatan pembelajaran). Strategi pembelajaran/skenario/tahapan-tahapan proses belajar mengajar yaitu kegiatan pembelajaran secara konkret yang harus dilakukan oleh guru dan siswa dalam berinteraksi dengan materi pembelajaran dan sumber belajar untuk menguasai kompetensi.

\section{Mengukur Kompetensi Siswa}

Setiap siswa mempunyai potensi yang siap untuk dikembangkan dalam hal ini pelaksanan pretes adalah bagian terpenting dalam proses pendidikan, karena potensi awal adalah 
sejumlah potensi yang dimiliki anak baik berkaitan dengan ilmu yang akan disampaikan, maupun dalam berbagai ilmu pengetahuan lain yang didapatkan sebelumnya. Proses belajar pada dasarnya selalu dipengaruhi oleh berbagai faktor, baik yang berasal dari dalam diri maupun dari luar diri si pebelajar. Faktor yang berasal dari dalam yang mempengaruhi berhasil atau tidak berhasil suatu pencapaian tujuan dalam proses belajar adalah potensi awal si pebelajar.

Potensi awal merupakan faktor penting sebagai bekal si pebelajar sebelum memasuki kegiatan pembelajaran. banyak ahli yang menyebutkan bahwa potensi awal sama dengan potensi yang dimiliki anak sejak dilahirkan ke bumi ini. Potensi ini ialah sejumlah potensi yang diberikan Allah kepada segenap manusia sebagai modal untuk mengelola alam semesta, sebagaimana ayat Alquran surat Ar-Rum ayat 30:

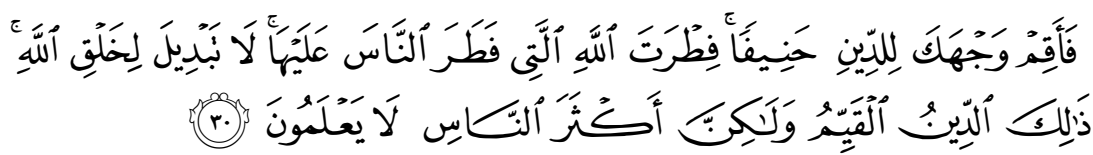

"Maka hadapkanlah wajahmu dengan lurus kepada Agama Allah, tetaplah atas fitrah Allah yang telah menciptakan manusia menurut fitrah itu. Tidak ada perubahan pada fitrah Allah. Itulah agama yang lurus, tetapi kebanyakan manusia tidak mengetahui."

Ayat di atas menegaskan bahwa pada dasarnya manusia telah mempunyai potensi yang disebut fitrah. Hal ini jelas bahwa dalam proses di sekolah, prestasi belajar yang diperoleh oleh si pebelajar sebelumnya memiliki pengaruh yang kuat terhadap prestasi belajar berikutnya. Hasil belajar dari suatu kegiatan belajar mencerminkan ciri-ciri awal si pebelajar yang digunakan untuk kegiatan berikutnya. Dalam proses pembelajaran potensi awal sangat penting, sebagaimana ditegaskan bahwa pentingnya potensi awal disebabkan karena mempunyai implikasi terhadap penyusunan bahan ajar dan system pembelajaran.

Penjelasan di atas dapat dikatakan bahwa potensi awal merupakan informasi yang penting bagi guru atau pendidik, agar dapat menetapkan metode dan pendekatan yang akan digunakan dalam kegiatan pembelajaran. Secara umum diketahui bahwa potensi awal sebagai kesiapan psikis dalam belajar, sebagaimana terurai pada 
ungkapan terdahulu, dapat berpengaruh terhadap semua proses belajar mengajar di dalam kelas. Potensi awal bukan hanya dilihat dari keadaan siswa saja, melainkan guru juga. Guru dan siswa berinteraksi dan berkomunikasi.

Proses belajar mengajar berlangsung di suatu sekolah sebagai institusi pendidikan, mengatur keseluruhap kehidupan sekolah. Menurut W.S. Winkel (2005: 4), potensi awal meliputi aspekaspek, yatu :1) Pribadi siswa, 2) Pribadi guru, 3) Struktur jaringan hubungan sosial di sekolah, 4) Sekolah sebagai institusi pendidikan, 5). Faktor situasional. Semua aspek ini dengan satu atau lain cara dapat mempengaruhi proses belajar mengajar di dalam kelas.

Namun demikian hal tersebut tidak merupakan salah satu komponen dalam proses belajar mengajar. Aspek potensi awal ini mencakup hal-hal seperti taraf intelegensi, daya kreativitas, potensi berbahasa, kecepatan belajar, kadar motivasi belajar, sikap terhadap tugas belajar, minat dalam belajar, perasaan dalam belajar serta keadaan mental dan fisik. Dalam potensi intelegensi terdapat taraftaraf, mulai dari taraf intelegensi yang tinggi sampai kepada taraf integensi yang rendah. Bagi seorang guru perlu untuk mengetahui hal ini, karena banyak manfaat yang didapatkan, diantaranya ialah guru tersebut dapat mengetahui pula taraf prestasi yang dapat diharapkan dari siswa tertentu.

Daya kreativitas menunjuk kepada potensi untuk berpikir yang lebih orisinal dibandingkan dengan kebanyakan orang lain. Dalam berfikir kreatif lebih berperan dan hal ini biasa disebut dengan berfikir divergen. "Berfikir Divergen, yaitu corak berfikir yang mencari jalan-jalan baru, lebih-lebih dalam memecahkan problem."Corak berfikir ini dilawankan dengan berfikir konvergen. "Berfikir Konvergen, yaitu corak berfikir yang mengikuti jalur yang diketahui pasti akan membawa hasil." Potensi intelektual tidak sama dengan potensi belajar. Semakin tinggi potensi belajar, akan semakin besar kemungkinan untuk berhasil di jenjang itu dengan taraf keberhasilan yang semakin tinggi pula. Potensi belajar merupakan perpaduan dari sejumlah komponen, yaitu potensi intelektual, bakat khusus, organisasi kognitif, luas pengetahuan yang dimiliki potensi berbahasa dan teknik-teknik studi. Namun komponen yang pertama lebih besar peranannya dibanding dengan komponen yang lain, dalam menentukan taraf 
potensi belajar.

Ada beberapa hal yang menyangkut kepribadian siswa yang juga menyangkut potensi awal siswa, yaitu:

1. Setiap siswa memiliki individualitas biologis sendiri

2. Kondisi mental

3. Vitalitas psikis

4. Lingkungan hidup

5. Perkembangan kepribadian.

Lima hal di atas merupakan potensi awal yang menyangkut kepribadian siswa. Individualitas biologis mencakup susunan kimiawi badan, susunan alat-alat perlengkapan badan, daya tahan terhadap penyakit dan daya hidup, dan bentuk badan yang khas untuk setiap manusia. Dengan demikian jelas bahwa bila seorang siswa sering sakit, maka konsentrasi belajarnya akan terganggu.

Begitu pula bila alat pendengaran dan penglihatan kurang, tentu akan mengganggu kegiatan belajar juga. Kondisi mental merupakan akibat dari keadaan psikis siswa, seperti ketenangan batin atau kegelisahan batin. Siswa yang menikmati ketenangan batin, karena kehidupan keluarganya yang harmonis dan pergaulan sosialnya dengan teman sebaya lancar, akan jauh lebih mudah untuk berkonsentrasi dalam belajar. Vitalitas psikis ini menunjuk pada jumlah dan kekuatan energi yang dimiliki seseorang dan berkaitan erat dengan daya hidup jasmani. Orang yang badannya mudah merasa lesu, cepat lelah dan kerap merasa lemah, tidak akan memiliki energi yang banyak.

Lingkungan hidup adalah keadaan yang melingkupi siswa atau keadaan yang dengan kehadirannya memberikan pengaruh pada perkembangan siswa. Keadaan sosio ekonomi menunjuk kepada taraf potensi finansial keluarga yang dapat bertaraf baik, cuku atau kurang. Keadaan ini tergantung sampai berapa jauh keluarga dapat membekali siswa dengan perlengkapan material untuk belajar. Perkembangan kepribadian, siswa yang berkembang secara normal, akan menampakkan ciri-ciri yang khas bagi berbagai taraf perkembangan. Guru harus mengetahui dan mempelajari psikologi perkembangan agar guru tersebut mengetahui potensi awal para siswanya. 
Ciri-ciri khas kepribadian guru, untuk sebahagian akan tampak dalam cara guru tersebut melakukan pekerjaannya. Kenyataan ini terlihat dari kehadirannya di kelas, dimana guru sudah memberikan pengaruh terhadap perkembangan siswa. Sebagai manusia, guru berpegang pada nilai-nilai tertentu yang akan menampakkan diri dalam pembicaraan dan tingkah laku di depan kelas, serta bertanggung jawab dalam bertindak. Menjadi seorang guru mengandung tantangan karena di satu pihak harus menerima siswa seadanya dan mampu menyelami alam pikiran siswa, namun di lain pihak harus mendorong siswa untuk berkembang lebih jauh dan mengatasi kekurangan yang masih ada padanya. Seorang guru juga harus menjadi teman bagi siswanya, namun guru juga tidak boleh lupa bahwa guru juga harus menuntun siswa untuk mencapai tingkat kehidupan manusiawi yang lebih sempurna.

Oleh karena itu, seorang guru selain bersikap empatik (menyelami alam pikiran dan perasaan siswa), guru juga harus menjadi inspirator yang memberikan semangat kepada siswa untuk berkembang lebih jauh dan juga menjadi seorang korektor yang tidak menuruti setiap keinginan siswa begitu saja. Dengan demikian sangat jelas bahwa guru sebagai pemegang amanat dan guru bertanggung jawab atas amanat yang diserahkan kepadanya. Allah menjelaskan dalam Q.S al-Nisa' ayat 58:

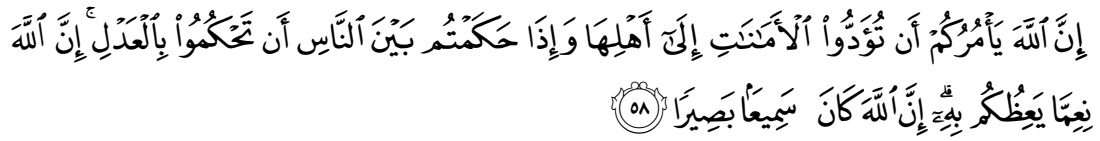

Sesungguhnya Allah menyuruh kamu menyampaikan amanat kepada yang berhak menerimanya, dan (menyuruh kamu) apabila menetapkan hukum di antara manusia supaya kamu menetapkan dengan adil. Sesungguhnya Allah memberi pengajaran yang sebaik-baiknya kepadamu. Sesungguhnya Allah adalah Maha Mendengar lagi Maha Melihat.

\section{Prinsip Remedial}

Menurut Depdiknas (2008) tentang Panduan Penyelenggaraan Pembelajaran Remedial, prinsip yang harus dipegang dalam pelaksanaan remedial adalah sebagai berikut.

a. Adaptif; Setiap peserta didik memiliki keunikan sendiri-sendiri dan mereka semuanya berbeda. Oleh karena itu program pembelajaran remedial hendaknya memungkinkan peserta 
didik untuk belajar sesuai dengan kecepatan, kesempatan, dan gaya belajar masing-masing. Dengan kata lain, pembelajaran remedial harus mengakomodasi perbedaan individual peserta didik.

b. Interaktif; Pembelajaran remedial hendaknya memungkinkan peserta didik untuk secara intensif berinteraksi dengan pendidik dan sumber belajar yang tersedia. Setiap kali mereka menemukan kesulitan, guru harus tanggap karena pada prinsipnya, remedial adalah proses perbaikan sehingga monitoring harus senantiasa dilakukan setiap waktu.

c. Fleksibilitas dalam Metode Pembelajaran dan Penilaian; Dalam aplikasinya, metode pembelajaran harus senantiasa berganti-ganti dan variatif. Guru harus mengembangkan dan menyesuaikan dengan kebutuhan dan karakteristik siswa sehingga semua siswa terakomodir dalam metode tersebut.

d. Pemberian Umpan Balik Sesegera Mungkin: Umpan balik berupa informasi yang diberikan kepada peserta didik mengenai kemajuan belajarnya perlu diberikan sesegera mungkin. Umpan balik dapat bersifat korektif maupun konfirmatif. Diharapkan, dengan umpan balik dapat meminimalisir kesalahan siswa.

e. Kesinambungan dan Ketersediaan dalam Pemberian Pelayanan: Program pembelajaran reguler dengan pembelajaran remedial merupakan satu kesatuan, sehingga keduanya harus saling melengkapi dan continue.

\section{Pelaksanaan Remedial dalam Mencapai Kompetensi Belajar}

Pembahasan ini akan diuraikan apa saja kompetensi yang ditargetkan dalam mempelajaran Agama Islam di sekolah, khususnya pada tingkat Sekolah Menengah. Kompetensi adalah kemampuan seseorang dalam menguasai dan melaksanakan ajaran agama yang dipelajari. Dalam pendidikan Islam terdapat sejumlah aspek yang diberikan kepada siswa, aspek-aspek ini dijadikan sebagai satu mata pelajaran yang berdiri sendiri namun tetap ada kaitannya dengan mata pelajaran lain. Kompetensi ini akan lebih jelas dan terukur melalui praktikum. Adapun aspekaspek yang dijadikan sebagai mata praktikum tersebut ialah aspek ibadah yang masuk kepada pelajaran fikih, aspek akhlak yang dijadikan sebagai bagian dari pelajaran agama, 
Alquran Hadis, Bahasa Arab, aspek sejarah Islam. Sedangkan pelajaran umum meliputi Ilmu Pengetahuan Sosial (IPS), Ilmu Pengetahuan Alam (IPA), Kesenian dan olah raga. Pengetahuan ibadah shalat sebagai salah bidang pembelajaran yang terdapat dalam pelajaran fikih, khususnya pengetahuan ibadah shalat adalah sebagai salah satu dari cabang ibadah yang sangat diprioritas guru dalam memberikan pemahaman dan pengalaman secara langsung tentang pelaksanaan ibadah shalat kepada siswa di madrasah.

Sebelum menguraikan secara khusus tentang ibadah, shalat terlebih dahulu dijelaskan pengertian ibadah, dari pengertian inilah akan dijabarkan apa pengertian ibadah shalat tersebut. Ibadah ialah sebagai wujud dari pengamalan dari ilmu pengetahuan yang diperoleh. Langkah yang digunakan untuk menanamkan kemampuan pengamalan ini, harus menggunakan metode yang tepat kepada peserta didik. Menurut para ahli, pengertian metode secara umum adalah cara atau kiat yang digunakan pendidik untuk menyampaikan materi, sehingga apa yang disampaikan dapat diterima dan dipahami peserta didik dengan baik.

Memperhatikan pengertian metode di atas, maka tentu saja banyak jenis metode yang dapat digunakan guru dalam menanamkan kemampuan pengamalan shalat siswa. Ada beberapa metode, misalnya Metode mengajar yang lazim digunakan guru di sekolah ialah; metode ceramah, memtode diskusi, metode tanya jawab, metode penugasan, metode praktikum, metode latihan, metode kerja kelompok dan metode drama. Salah satu sejumlah metode yang selalu digunakan ialah metode praktikum. Metode latihan tidak hanya dalam pembelajaran ilmu eksakta, seperti biologi, kimia, fisika dan sebagainya yang menggunakan berbagai peralatan di laboratorium. Dalam pembelajaran Agama Islam metode latihan juga sering digunakan, khususnya dalam pembelajaran ibadah shalat.

Pengamalan ibadah dapat diartikan dengan suatu kegiatan yang berusaha untuk mengaplikasikan dalam bentuk keterampilan (psikomotorik) dari pembelajaran yang dilaksanakan dengan metode latihan secara langsung terhadap ibadah, seperti ibadah shalat. Dalam metode ini siswa disuruh untuk melaksanakan atau melakukan secara langsung bagaimana proses pelaksanaan ibadah tersebut. Sehingga 
siswa merasakan atau mengalami langsung bagaimana melaskanakan ibadah tersebut. Membahas tentang pengamalan ibadah berarti menguraikan tentang ibadah sebagai kewajiban seorang Muslim. Ibadah ialah perintah Allah Swt kepada setiap Muslim untuk dilaksanakan dalam kehidupan sehari-hari. Ada dua aspek yang harus dilaksanakan manusia sebagai hamba Allah, yaitu melaksanakan aspek hablun min Allah, yaitu menjalin hubungan dengan Allah Swt. Ini dilakukan dalam bentuk melaksanakan ibadah yang diwajibkan, antara lain ibadah shalat, ibadah puasa, zakat, menunaikan haji. Sedangkan aspek kedua ialah menjalin hubungan dengan sesama manusia, yaitu dalam bentuk mu'amalah. Inilah yang disebut dengan manusia sebagai makhluk sosial. Karena itu manusia di muka bumi ini hendaknya sadar siapa dia, dari mana dia dan mau kemana dia. Dia tak dapat berdiri sendiri tanpa mengadakan hubungan dengan sesamanya, dengan alam sekitarnya serta dengan Penciptanya.

Dalam membina kehidupan, manusia tidak dapat hanya mengandalkan kemampuan akalnya semata, akan tetapi harus ada bimbinga serta petunjuk dari Yang Menciptakannya. Karena itulah maka Allah Swt yang Maha Tahu akan kelemahan yang ada pada diri manusia, memberikan bimbingan agar dalam kehidupannya manusia melalui Alquran selalu mengucapkan tunjukilah kami kejalan yang lurus Sebagaimana dalam Surat Al-Baqarah, ayat 4:

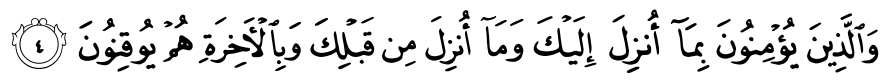

"Dan mereka yang beriman kepada kitab (Alquran) yang telah diturunkan kepadamu dan kitabkitab yang telah diiturunkan sebelumnya serta mereka yakin akan adanya (kehidupan) akhirat."

Manusia dibekali dengan akal pikiran yang membuatnya mampu untuk mengelola apa yang terdapat di alam semesta, mulai dari bentuk tumbuh-tumbuhan, lahan persawahan, ladang, hewan ternak dan sebagainya. Semua itu adalah sebagai amanah dari Allah kepada manusia untuk bekal kelangsungan hidup.

Perbedaan yang asasi antara manusia dan makhluk hidup lainnya, selain akal dan fungsinya yang dimiliki manusia, juga terletak pada tujuan hidupnya yang jelas. Jika manusia mempunyai tujuan hidup yang jelas, maka fungsi kekhalifahannya akan terlepas dari 
tangannya, dia akan seperti hewan yang hidupnya hanya sekedar untuk makan, minum dan berkembang biak.

Pengamalan ibadah adalah wujud dari penghambaan diri kepada Allah Swt. Manusia diciptakan Allah Swt dari sebaik-baik kejadian dan inilah yang menyebabkan Allah Swt memberikan amanah kepada manusia sebagai Khalifah. Ini dapat dilihat dalam Alquran, surat Baqarah ayat 30:

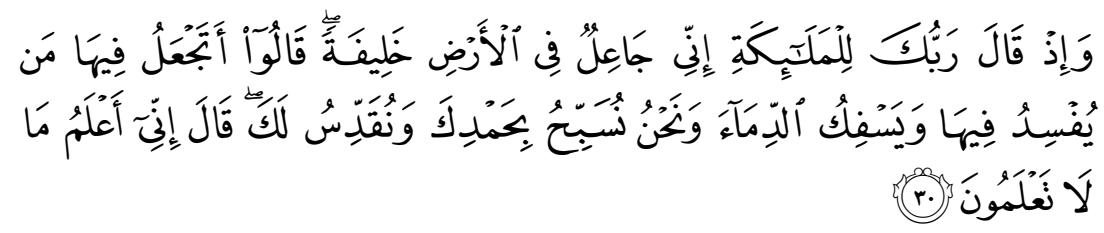

"Ingatlah ketika Tuhanmu berfirman kepada para Malaikat: Sesungguhnya Aku hendak menjadikan seorang Khalifah di muka bumi. Mereka berkata, mengapa Engkau hendak menjadikan (Khalifah) dibumi ini orang yang akan membuat kerusakan padanya dan menumpahkan darah, padahal kami senantiasa bertasbih dengan memuji Engkau dan mensucikan Engkau. Tuhan berfirman; Sesungguhnya Aku mengetahui apa yang tidak kamu ketahui."

Melalui ayat di atas jelaslah bahwa kelebihan yang diberikan Allah kepada manusia membuat dirinya mempunyai tanggung jawab yang besar dan mengemban tugas yang berat. Tetapi sekalipun tugas dan beban itu berat tetapi Allah telah menyesuaikannya dengan penciptan yang lebih sempurna dibanding dengan makhluk lain.

Hakikat ibadah ialah keyakinan akan kebenaran ajaran Islam dalam kehidupan ini disebut ibadah. Iman memberi watak bagi setiap Muslim untuk menjadikan setiap kegiatan hidupnya guna mengabdi kepada Allah. Seluruh hidupnya penuh dengan ketaatan dan ketundukan diri serta ia sekali-kali tidak akan bersikap sombong ataupun mengikuti kemauannya sendiri saja, terkecuali dalam keadaan lupa. Dan begitu sadar dari lupanya terdebut, ia akan kembali menyerahkan diri kepada Allah serta bertaubat atas kesalahannya itu.

Ibadah pada dasarnya dapat disamakan dengan amal shaleh. Ibadah ialah ketundukan yang terjadi karena jiwa merasakan kebesaran yang diibadahi. Lantaran menyakini adanya kekuasaan yang hakikatnya tak dapat diketahui akal. Iman adalah syarat utama bagi manusia dalam usaha mencapai kehidupan yang bahagia. Ibadah 
atau amal yang tidak dilandasi iman, tidak akan mempunyai apa-apa disisi Allah Swt. Abul-Al'la Maududi merumuskan ibadah ini sebagai berikut:

"Singkatnya, seluruh aktivitasmu dan ruang lingkup hidupmu adalah ibadah, jika dan hanya jika semua itu sesuai dengan hokum Allah dan hatimu dipenuhi dengan rasa takut kepada-Nya, dan jika akhir dari semua kegiatan itu untuk mencapai keridhaan Allah."

Secara tegas Allah menyatakan dalam Alquran surat Al-An'am, ayat 162 bahwa:

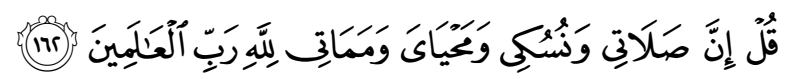

"Sesungguhnya shalatku, ibadahku, hidupku an matiku hanyalah untuk Allah Tuhan semesta alam."

Pengamalan ibadah dalam pelajaran agama Islam yang mudah diketahui dari kemampuan Siswa ialah pelaksanaan shalat. Dalam pelajaran Agama Islam shalat sebagai ibadah yang sangat penting ditanamkan. Sehingga pengetahuan Siswa tentang shalat akan dapat diukur secara psikomotorik melalui pelaksanaan shalat. Secara umum ada beberapa langkah pembelajaran yang juga berlaku dalam pembelajaran agama.

Langkah pembelajaran ini antara lain memotivasi siswa, melihat kebutuhan peserta didik, menumbuhkan persepsi yang sama terhadap materi praktikum, dan melaksanakan proses pembelajaran. Dalam praktikum ibadah materi pendidikan yang diberikan meliputi semua aspek-aspek ajaran agama, antara aspek akidah, mu'amalah, akhlak, ibadah, membaca Alquran dan Tarikh Islam. Aspek-apek pendidikan tersebut tentu saja tidak disampaikan secara luas dan mendalam kepada siswa apabila hanya mengharapkan waktu yang tersedia di kelas yang dimanfaatkan. Strategi pembelajaran agama yang didapatkan di sekolah umumnya masih bersifat konvensional, artinya guru masih lebih mewarnai proses pembelajaran. Berdasarkan Kurikulum 2004, peningkatan mutu pendidikan harus dilakukan secara menyeluruh yang mencakup pengembangan dimensi manusia Indonesia seutuhnya, yakni aspek-aspek moral, akhlak, budi pekerti, perilaku, pengetahuan, kesehatan, keterampilan dan seni. Pengembangan aspek-aspek tersebut bermuara pada peningkatan dan 
pengembangan kecakapan hidup yang diwujudkan melalui pencapaian kompetensi peserta didik untuk bertahan hidup, menyesuaikan diri dan berhasil di masa datang.

Dengan demikian peserta didik memiliki ketangguhan, kemandirian dan jati diri yang dikembangkan melalui pembelajaran dan pelatihan yang dilakukan secara bertahap dan berkesinambungan. Pendidikan Indonesia dapat dilakukan melalui dua aspek kegiatan, yakni kegiatan pembudayaan dan kegiatan pengajaran. Kegiatan pembudayaan adalah upaya mentransformasi nilainilai moral dan pembentukan kepribadian dengan berbagai aspek mental, spritual dan psikologis. "Kegiatan pengajaran bertalian dengan upaya mentransformasi dan penguasaan ilmu pengetahuan dan teknologi, sikap dan keterampilan serta penerapannya."

Dalam menyusun strategi pembelajaran inilah dapat dilihat keterkaitan praktikum dengan pembelajaran agama, khusus bidang ibadah sangat erat. Pembalajaran praktikum akan memberikan kesan dan pengalaman langsung kepada anak tentang apa yang dipelajari. Inilah sebenarnya salah satu visi pendidikan berbasis teknologi tersebut. Perkembangan dan kemajuan teknologi dewasa ini tidak terlepas dari perkembangan dan kemajuan ilmu pengetahuan. Sejalan dengan perkembangan dan kemajuan ilrnu pengetahuan tersebut maka praktikum ibadahsebagai suatu ilmu yang banyak peranannya, baik sebagai individu maupun bagi perkembangan genarasi muda dalam suatu negara. Dengan demikian praktikum ibadahdiajarkan sebagai materi praktikum sejak dari Sekolah Menengah hingga sekolah menengah atas, dan spesialisasinya di perguruan tinggi. Sebaiknya guru harus lebih banyak menggunakan pendekatan pembelajaran praktikum dalam mengajarkan ibadah kepada siswa muai dari tingkat Sekolah Menengah sampai sekolah lanjutan.

Untuk melaksanakan remedial harus dipahami terlebih dahulu apa itu remedial. Memahami Kegiatan Remedial dan Pengayaan untuk Perbaikan Pembelajaran Kegiatan remedial adalah kegiatan yang ditujukan untuk membantu siswa yang mengalami kesulitan dalam menguasai materi pelajaran. Sesuai dengan pengertiannya, tujuan kegiatan remedial ialah membantu siswa mencapai tujuan pembelajaran yang telah ditetapkan dalam kurikulum yang berlaku. 
Dalam kaitannya dengan proses pembelajaran, fungsi kegiatan remedial adalah:

1. Memperbaiki cara belajar siswa dan cara mengajar guru (fungsi korektif).

2. Meningkatkan pemahaman guru dan siswa terhadap kelebihan dan kekurangan dirinya (fungsi pemahaman).

3. Menyesuaikan pembelajaran dengan karakteristik siswa (fungsi penyesuaian).

4. Mempercepat penguasaan siswa terhadap materi pelajaran (fungsi akselerasi). Membantu mengatasi kesulitan siswa dalam aspek sosial-pribadi (fungsi terapeutik).

Perbedaan kegiatan remedial dari pembelajaran biasa terletak pada pendekatan yang digunakan dalam perencanaan dan pelaksanaan pembelajaran. Kegiatan remedial direncanakan dan dilaksanakan berdasarkan kebutuhan individu atau kelompok siswa. Sedangkan pembelajaran biasa menerapkan pendekatan klasikal, baik dalam perencanaan maupun dalam pelaksanaannya. Kegiatan remedial dapat dilaksanakan sebelum kegiatan pembelajaran biasa untuk membantu siswa yang diduga akan mengalami kesulitan (preventif); setelah kegiatan pembelajaran biasa untuk membantu siswa yang mengalami kesulitan belajar (kuratif); atau selama berlangsungnya kegiatan pembelajaran biasa (pengembangan).

Dalam melaksanakan kegiatan remedial guru dapat menerapkan berbagai metode dan media sesuai dengan kesulitan yang dihadapi dan tingkat kemampuan siswa serta menekankan pada segi kekuatan yang dimiliki siswa. Langkah-langkah yang harus ditempuh dalam kegiatan remedial adalah:

1. Analisis hasil diagnosis kesulitan belajar,

2. Menemukan penyebab kesulitan,

3. Menyusun rencana kegiatan remedial,

4. Melaksanakan kegiatan remedial, dan

5. Menilai kegiatan remedial

6. Kegiatan

7. Pengayaan.

Dalam memilih dan melaksanakan kegiatan pengayaan, guru harus memperhatikan: 
1. Faktor siswa, baik faktor minat maupun faktor psikologis lainnya,

2. Faktor manfaat edukatif.

3. Faktor waktu.

Julaeha dkk (2007: 38) menyebutkan faktor-faktor penting lainnya yang juga harus diperhatikan oleh pendidik atau guru dalam menentukan dan memilih kegiatan pengayaan.

a. Siswa lebih menyukai kegiatan di luar kelas

b. Siswa lebih suka beraktivitas dari pada hanya berteori

c. Kegiatan observasi yang baru lebih merangsang minat siswa dibanding kegiatan yang sifatnya penjelasan

d. Kegiatan yang dengan cepat dapat menunjukkan hasil, lebih disukai siswa dari pada yang waktunya lama

Dalam rangka membantu peserta didik mencapai standar isi dan standar kompetensi lulusan, pelaksanaan atau proses pembelajaran perlu diusahakan agar interaktif, inspiratif, menyenangkan, menantang, memotivasi peserta didik untuk berpartisipasi aktif, serta memberikan kesempatan yang cukup bagi prakarsa, kreativitas, dan kemandirian sesuai dengan bakat, minat, dan perkembangan fisik serta psikologis peserta didik. Kendati demikian, tidak dapat dipungkiri bahwa untuk mencapai tujuan dan prinsip-prinsip pembelajaran tersebut pasti dijumpai adanya peserta didik yang mengalami kesulitan atau masalah belajar. Untuk mengatasi masalah-masalah tersebut, setiap satuan pendidikan perlu menyelenggarakan program pembelajaran remedial atau perbaikan.

Pembelajaran remedial merupakan layanan pendidikan yang diberikan kepada peserta didik untuk memperbaiki prestasi belajarnya sehingga mencapai kriteria ketuntasan yang ditetapkan. Untuk memahami konsep penyelenggaraan model pembelajaran remedial, terlebih dahulu perlu diperhatikan bahwa Kurikulum Tingkat Satuan Pendidikan (KTSP) yang diberlakukan berdasarkan Permendiknas 22, 23, 24 Tahun 2006 dan Permendiknas Nomor 6 Tahun 2007 menerapkan sistem pembelajaran berbasis kompetensi, sistem belajar tuntas, dan sistem pembelajaran yang memperhatikan perbedaan individual peserta didik. Sistem dimaksud ditandai dengan dirumuskannya secara jelas standar kompetensi (SK) dan kompetensi 
dasar (KD) yang harus dikuasai peserta didik. Penguasaan SK dan $\mathrm{KD}$ setiap peserta didik diukur menggunakan sistem penilaian acuan kriteria. Jika seorang peserta didik mencapai standar tertentu maka peserta didik dinyatakan telah mencapai ketuntasan.

Pelaksanaan pembelajaran berbasis kompetensi dan pembelajaran tuntas, dimulai dari penilaian kemampuan awal peserta didik terhadap kompetensi atau materi yang akan dipelajari. Kemudian dilaksanakan pembelajaran menggunakan berbagai metode seperti ceramah, demonstrasi, pembelajaran kolaboratif/ kooperatif, inquiry dan discovery. Melengkapi metode pembelajaran digunakan juga berbagai media seperti media audio, video, dan audiovisual dalam berbagai format, mulai dari kaset audio, slide, video, komputer, multimedia, dan sebagainya. Proses pelaksanaan pembelajaran atau pada saat kegiatan pembelajaran sedang berlangsung, diadakan penilaian proses menggunakan berbagai teknik dan instrumen dengan tujuan untuk mengetahui kemajuan belajar serta seberapa jauh penguasaan peserta didik terhadap kompetensi yang telah atau sedang dipelajari. Pada akhir program pembelajaran, diadakan penilaian yang lebih formal berupa ulangan harian. Ulangan harian dimaksudkan untuk menentukan tingkat pencapaian belajar peserta didik, apakah seorang peserta didik gagal atau berhasil mencapai tingkat penguasaan tertentu yang telah dirumuskan pada saat pembelajaran direncanakan.

Apabila dijumpai adanya peserta didik yang tidak mencapai penguasaan kompetensi yang telah ditentukan, maka muncul permasalahan mengenai apa yang harus dilakukan oleh pendidik. Salah satu tindakan yang diperlukan adalah pemberian program pembelajaran remedial atau perbaikan. Dengan kata lain, remedial diperlukan bagi peserta didik yang belum mencapai kemampuan minimal yang ditetapkan dalam rencana pelaksanaan pembelajaran. Pemberian program pembelajaran remedial didasarkan atas latar belakang bahwa pendidik perlu memperhatikan perbedaan individual peserta didik.

Dengan diberikannya pembelajaran remedial bagi peserta didik yang belum mencapai tingkat ketuntasan belajar, maka peserta didik ini memerlukan waktu lebih lama daripada mereka yang telah 
mencapai tingkat penguasaan. Mereka juga perlu menempuh penilaian kembali setelah mendapatkan program pembelajaran remedial.

\section{Simpulan}

Adapun langkah-langkah pelaksanaan pembelajaran remedial dalam mencapai kompetensi belajar ialah:

1. Adaptif, artinya: setiap peserta didik memiliki keunikan sendiri-sendiri.

2. Interaktif, artinya: pembelajaran remedial hendaknya memungkinkan peserta didik

3. untuk secara intensif berinteraksi dengan pendidik dan sumber belajar yang tersedia.

4. Fleksibilitas dalam metode pembelajaran dan penilaian, artinya: sejalan dengan sifat keunikan dan kesulitan belajar peserta didik yang berbeda-beda.

5. Pemberian Umpan Balik Sesegera Mungkin, artinya: umpan balik berupa informasi yang diberikan kepada peserta didik mengenai kemajuan belajarnya perlu diberikan sesegera mungkin.

6. Kesinambungan dan Ketersediaan dalam Pemberian Pelayanan, artinya: program pembelajaran reguler dengan pembelajaran remedial merupakan satu kesatuan, dengan demikian program pembelajaran reguler dengan remedial harus berkesinambungan dan programnya selalu tersedia agar setiap saat peserta didik dapat mengaksesnya sesuai dengan kesempatan masing-masing. 


\section{DAFTAR PUSTAKA}

Julaeha, dkk. 2007. Belajar Dan Pembelajaran 2. Jakarta: Universitas Terbuka.

Depdiknas. 2008. Sistem Penilaian KTSP: Panduan Penyelenggaraan Pembelajaran Remedial

Majid, Abdul. 2011. Perencanaan Pembelajaran. Bandung: Remaja Rosdakarya.

Nazir, M. 2003. Metode Penelitian. Jakarta: Ghalia Indonesia, cet. ke-5.

Rice, Valerie L. 2013. ROPES: a Model to Increase Learning Outcome. Attorney at Law.

Sardiman. 2011. Interaksi dan Motivasi Belajar Mengajar. Jakarta: Rajawali Press

Sutikno, M. Sobri. 2009. Belajar dan Pembelajaran. Bandung: Prospect.

Syah, Muhibbin. 2010. Psikologi Pendidikan dengan Pendekatan Baru. Bandung: PT. Remaja Rosdakarya.

Tim Penyusun Kamus Pusat Bahasa. 2008. Kamus Bahasa Indonesia. Jakarta: Pusat Bahasa Departemen Pendidikan Nasional.

WS. Winkel. 1996. Psikologi Belajar. Jakarta: Sinar Grafindo Persada. 
Nasruddin Hasibuan

halaman ini bukan sengaja dikosongkan 